\title{
Prolactin Response to TRH in Diabetic Ketoacidosis
}

\author{
R. Naeije ${ }^{1}$, M. Badawi ${ }^{2}$, L. Vanhaelst ${ }^{3}$, A. Cornil ${ }^{1}$, and M. L'Hermite ${ }^{2}$ \\ ${ }^{1}$ Intensive Care Unit, St. Pierre Hospital, ${ }^{2}$ Human Reproduction Unit, and ${ }^{3}$ Laboratory of Experimental Medicine, \\ Universities of Brussels, Brussels, Belgium
}

\begin{abstract}
Summary. The prolactin response to $200 \mu \mathrm{g}$ thyrotropin-releasing hormone (TRH) IV was studied in seven patients with diabetic ketoacidosis, at the start of the treatment, and again, in the same patients, five days after recovery, when the diabetes was well controlled. Normal basal prolactin concentrations and prolactin responses to TRH were found in both situations. There was no correlation between basal prolactin concentrations, or magnitude of prolactin responses to TRH, and any of the metabolic variables measured. These findings do not suggest a role for prolactin in the development of diabetic ketoacidosis.
\end{abstract}

Key words: Prolactin, diabetic ketoacidosis, plasma sodium, plasma osmolality, TRH test.

Prolactin is said to have diabetogenic properties [ 1 , 2] and, in several animal species, plays a role in sodium and water retention [3]. Elevated prolactin concentrations have been reported in diabetic ketoacidosis and it was suggested that prolactin might participate in sodium retention in this condition [4].

We recently showed that patients with diabetic ketoacidosis have an abnormally low thyrotropin (TSH) response to thyrotropin-releasing hormone (TRH), in the face of reduced thyroxine $\left(\mathrm{T}_{4}\right)$ and triiodothyronine $\left(T_{3}\right)$ concentrations [5]. Since TRH is also known to be a potent stimulator of prolactin secretion [6], it was considered of interest to investigate the reactivity of the pituitary prolactin cells to TRH in diabetic ketoacidosis.

\section{Material and Methods}

Seven patients with severe diabetic ketoacidosis were studied, 5 men and 2 women, age range 20 to 74 years $(37 \pm 7$, mean \pm SEM), body weight range 82 to $117 \%$ of ideal body weight ( $96 \pm$ $4.5)$. The precipitating event was infection in 3 and omission of insulin in the others. None of the patients had clinical evidence of pituitary or thyroid disease. None of them used drugs known to affect prolactin secretion. Tests for glycosuria and ketonuria were strongly positive. Plasma glucose ranged from 400 to $830 \mathrm{mg} / \mathrm{dl}$ $(615 \pm 60 \mathrm{mg} / \mathrm{dl}$, mean $\pm \mathrm{SEM})$; arterial blood $\mathrm{pH}$ from 6.80 to 7.21 (7.06 \pm 0.05$)$; plasma sodium from 119 to $143 \mathrm{mmol} / \mathrm{l}(130$

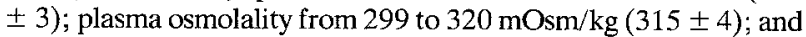
plasma bicarbonate from 2 to $5.5 \mathrm{mmol} / \mathrm{l}(3.5 \pm 0.5)$. Five of the patients have been reported elsewhere, in a study on thyroid function in diabetic ketoacidosis [5]. All the patients were treated with a standard regimen as described previously, the insulin dosage being $20 \mathrm{IU} / \mathrm{hr}$ [7]. The mean duration of treatment was $6 \mathrm{~h}$. Once the plasma glucose had reached $250 \mathrm{mg} / \mathrm{dl}$, the patients received a $2000-2500 \mathrm{kcal}$ diabetic diet and subcutaneous insulin according to glycosuria. After an average of $24 \mathrm{~h}$, good control of the diabetes was achieved (i. e. no ketonuria and plasma glucose below $300 \mathrm{mg} / \mathrm{dl}$ ).

Synthetic thyrotropin-releasing hormone (TRH, Roche Laboratories) $200 \mu \mathrm{g}$ was injected IV on admission, at the same time as the first insulin bolus, and again after 5 days good control of the diabetes. Blood was drawn at $-15,0,15,30,45,60,90$, and $120 \mathrm{~min}$ for prolactin determinations. Seven healthy volunteers, 5 men and 2 women, age range 24 to 65 years ( $35 \pm 6$ ), body weight range 96 to $103 \%$ of ideal body weight $(99 \pm 2)$ were matched by sex and as closely as possible by age. Informed consent was obtained from all the subjects, or from the relatives of the comatose patients. All the control TRH tests were performed between 08.00 and 10.00 hours.

Serum prolactin was measured by a radioimmunoassay using non-equilibrium double antibody conditions previously described [8], and the homologous human reagents kindly distributed by the NIAMDD as VLS kit $n^{\circ} 3$ [9]. A pool of sera collected from women in the immediate post partum period served as a laboratory standard. The results were expressed as $\mathrm{mU} / \mathrm{ml}$ of this standard: 1 $\mathrm{mU}$ was found to be equivalent to $2.3 \mu \mathrm{U}$ of the research standard $71 / 222$ provided by the MRC (Holly Hill, London, England).

The secretory area, i.e. the area between the baseline of $0 \mathrm{~min}$ and the curve drawn through the values measured at different times after $0 \mathrm{~min}$, was used as index of the prolactin response to 


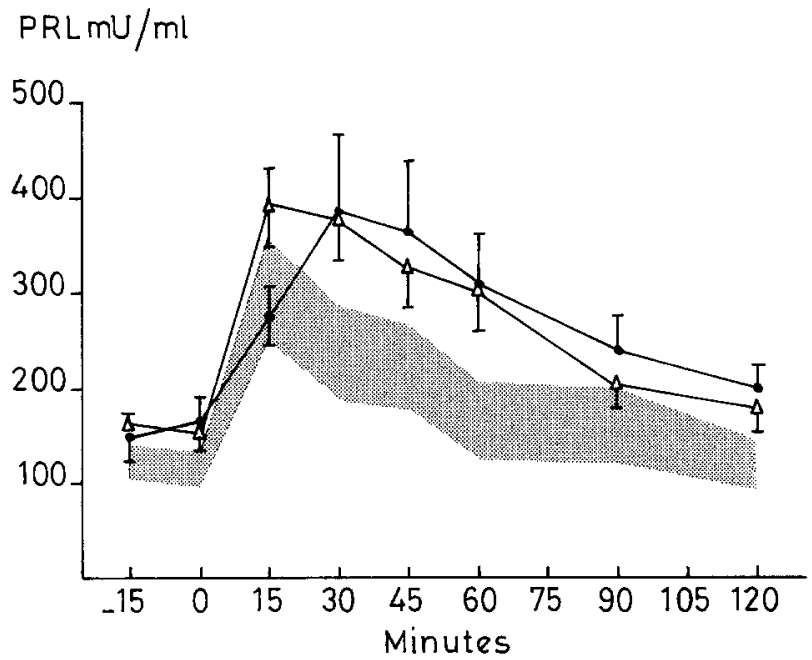

Fig. 1. Mean \pm SEM serum prolactin concentrations after $200 \mu \mathrm{g}$ TRH IV in patients with diabetic ketoacidosis on admission $(\bullet-)$, after 5 days good control of diabetes $(\triangle-\triangle)$. The stippled area represents mean \pm SEM values for normal controls

TRH. The statistical analysis was done using the Wilcoxon matched-pairs sign-ranks test, the Mann-Whitney U test and correlation coefficient calculations.

\section{Results}

Basal ( -15 and $0 \mathrm{~min}$ ) serum prolactin on admission was $168 \pm 30 \mathrm{mU} / \mathrm{ml}$ (mean $\pm \mathrm{SEM}$ ), not significantly different from the same patients 5 days after recovery $(157 \pm 13 \mathrm{mU} / \mathrm{ml})$ or from the normal controls $(123 \pm 17 \mathrm{mU} / \mathrm{ml})$. There was no correlation between basal serum prolactin and arterial $\mathrm{pH}$ or plasma sodium, bicarbonate and osmolality.

The secretory area of prolactin response to $\mathrm{TRH}$ (Fig. 1) was on admission $15,719 \pm 4,546 \mathrm{mU} \times$ $\mathrm{min} / \mathrm{ml}$, not significantly different from the same patients 5 days after recovery $(16,961 \pm 3,299 \mathrm{mU}$ $\times \mathrm{min} / \mathrm{ml})$ or from the normal controls $(10,525 \pm$ $3,171 \mathrm{mU} \times \mathrm{min} / \mathrm{ml}$ ). There was no correlation between these secretory areas and arterial blood $\mathrm{pH}$ or plasma sodium, bicarbonate and osmolality. It is apparent on the figure that the response curves of the diabetics, during and after diabetic decompensation, are situated at a higher level than the response curves of the normal controls. However, the difference was not significant.

\section{Discussion}

Pituitary hormones are of importance in the development of diabetic ketoacidosis, but the respective roles of each of them remain to be established [10]. Prolactin has diabetogenic properties, at least at very high circulating levels as in patients with pituitary adenomas $[1,2]$. We found normal basal prolactin concentrations and normal prolactin responses to TRH in patients with severe diabetic ketoacidosis, suggesting no important role for prolactin in this condition.

Our findings are at variance with the only other available study on the subject [4], in which elevated prolactin concentrations were reported in 8 ketoacidotic patients. The scatter of their prolactin values was wide, and, considering the SEM values, some of the patients might have presented with normal prolactin concentrations. There was no information on precipitating factors nor whether the patients used drugs affecting prolactin secretion. Differences in precipitating factors, e.g. stress [11], or in drug usage could account for the discrepancies between the two studies.

In our patients, no correlation could be found between prolactin concentrations and plasma osmolality or sodium levels. Prolactin plays a role in sodium and water retention in fishes and some species of mammals [3]. Although there has been some controversy, this has not been established with certainty in humans [12]. We cannot support the speculation of Hanssen and Torjesen that prolactin might participate in sodium retention in diabetic ketoacidosis [4].

Patients with diabetic ketoacidosis have lowered $\mathrm{T}_{3}$ and $\mathrm{T}_{4}$ concentrations, and a blunted TSH response to TRH [5]. Our patients had normal prolactin responses to TRH, suggesting that the pituitary abnormality of the "low $T_{3}$ syndrome" of diabetic ketoacidosis is selectively situated at the TSH secreting pituitary cells.

In conclusion, basal prolactin concentrations and TRH stimulated prolactin secretion are normal in diabetic ketoacidosis. Prolactin does not appear to play an important role in the development of diabetic decompensation.

\begin{abstract}
Acknowledgements. We thank the nurses and the medical staff of the Intensive Care Unit for their help in caring for the patients. The secretarial help of Miss Ann Vanhaelewijck was greatly appreciated. We thank the National Pituitary Agency, Endocrinology Study Section, and the National Institute of Arthritis and Metabolic Diseases for supplying the reagents used for PRL assays. This work was supported by grants to Prof. P. O. Hubinont by the Fonds de la Recherche Scientifique (Belgium) and the Ford Foundation (USA). M. Badawi was a postdoctoral fellow of the Ford Foundation; his present address is: National Organization of Drug Research and Control, Giza, Pyramide, Cairo, Egypt.
\end{abstract}

\section{References}

1. Landgraf, R., Landgraf-Leurs, M. M. C., Weissmann, A., Hörl, R., von Werder, K., Scriba, P.C.: Prolactin: A diabetogenic hormone. Diabetologia 13, 99-104 (1977) 
2. Tourniaire, J., Pallo, D., Pousset, G., Bizollon, C., Bachelot, I.: Diminution de la tolérance glucidique et hyperinsulinisme dans l'adénome à prolactine. Nouv. Presse Méd. 3, 1705-1707 (1974)

3. Nicoll C. S.: Physiological actions of prolactin. In: Handbook of physiology. Knobil, E., Sawyer (Eds.), Section 7, Vol 4, part 2, chap. 32, pp. 253-292. Washington: Williams and Wilkins 1974

4. Hanssen, K. F., Torjesen, P. A.: Increased prolactin in diabetic ketoacidosis: correlation between serum sodium and serum prolactin concentration. Acta Endocrinol (Kbh.) 85, 372-378 (1977)

5. Naeije, R., Golstein, J., Clumeck, N., Meinhold, H., Wenzel, K.W., Vanhaelst, L.: A low $\mathrm{T}_{3}$ syndrome in diabetic ketoacidosis. Clin. Endocrinol. (Oxf.) 8, 467-472 (1978)

6. L'Hermite, M., Vanhaelst, L., Copinschi, G., Leclercq, R., Golstein, J., Bruno, O. D., Robyn, C.: Prolactin release after injection of thyrotropin-releasing hormone in man. Lancet 1972 I, 762-765

7. Clumeck, N., De Troyer, A., Naeije, R., Somers, G., Smekens, L., Balasse, E. O.: Treatment of diabetic coma with small intravenous insulin boluses. Br. Med. J. 1976 II, 394-396.

8. L'Hermite, M., Midgley, A. R.: Radioimmunoassay of human follicle-stimulating hormone with antisera to the ovine hormone. J. Clin. Endocrinol. Metab. 33, 68-76 (1971)

9. Badawi, M., Bila, M., L'Hermite, M., Perez-Lopez, F.R., Robyn, D.: Comparative evaluation of radioimmunoassay methods for human prolactin using anti-ovine and anti-human prolactin sera. In: Radioimmunoassay and related procedures in medicine, Vol 1, pp 411-412. Vienna: International Atomic Energy Agency 1974

10. Barnes, A. J., Kohner, E. M., Bloom, S. R., Johnston, D. G., Alberti, K. G. M. M., Smythe, P.: Importance of pituitary hormones in aetiology of diabetic ketoacidosis. Lancet $1978 \mathrm{I}$, 1171-1174

11. Noel, G. L., Suh, H. K., Stone, J. G., Frantz, A. G.: Human prolactin and growth hormone release during surgery and other conditions of stress. J. Clin. Endocrinol. Metab. 35, 850-851 (1972)

12. Adler, R. A., Noel, G. L., Wartowsky, L., Frantz, A. G.: Failure of oral water loading and intravenous hypotonic saline to suppress plasma prolactin in man. I. Clin. Endocrinol. Metab. 41, 383-389 (1975)

Received: August 31, 1978,

and in revised form: February 23, 1979

Dr. R. Naeije

Service de Médecine

Hôpital St. Pierre

322, Rue Haute

B-1000 Bruxelles

Belgium 